\title{
Electrotransformation of Streptococcus pneumoniae : evidence for restriction of DNA on entry
}

\author{
Jacques Lefrançois and A. Michel Sicard \\ Author for correspondence: J. Lefrançois. Tel: +3361335971. Fax: +33613358 86. \\ e-mail: Jacques@IBCG.biotoul.fr
}

Laboratoire de Microbiologie et Génétique Moléculaire du CNRS and Université Paul Sabatier, 118 route de Narbonne, 31062

Toulouse Cedex, France

\begin{abstract}
Electrotransformation is a method generally used in biotechnology to introduce recombinant DNA into a wide range of bacteria. However, the mechanism of DNA entry is poorly understood. We report that in Streptococcus pneumoniae, a naturally transformable species, electrotransformation efficiently introduces a plasmid replicon. DNA is strongly restricted by the restriction-modification systems DpnI and Dpnll which degrade methylated and non-methylated DNA, respectively, at GATC sequences. This suggests that in electrotransformation double-stranded DNA penetrates into these bacteria without a single-stranded DNA step in contrast to natural transformation. Single-stranded DNA by itself is able to electrotransform very weakly and linearized double-stranded plasmid DNA yields barely detectable levels of transformants.
\end{abstract}

Keywords: Streptococcus pneumoniae, electrotransformation, restriction, DNA uptake

\section{INTRODUCTION}

Molecular genetics and biotechnology have undergone tremendous development as a result of the discovery of various methods that facilitate the exchange of genetic material. The first successful method was the natural transformation of Streptococcus pneumoniae by DNA (Avery et al., 1944). However, remarkably few naturally transformable species have been described. There is a necessity to use recombinant DNA technology in a range of bacteria of economic significance. For bacteria lacking a natural mechanism for DNA uptake, techniques have been devised to introduce DNA. The most efficient of these is electrotransformation (see Chassy $e t$ al., 1988, for a review). When exposed to high electric fields (up to $12 \mathrm{kV} \mathrm{cm}^{-1}$ ) for very short periods (a few milliseconds), DNA penetrates bacterial cells and transformants can be obtained. Much work has been devoted to optimize electrotransformation in various species as a method for the construction of recombinant strains. Experiments to elucidate the mechanism of DNA entry have given divergent results in several systems (Klenchim et al., 1991; Eynard et al., 1992). Little effort has been devoted to understanding if there is any structural modification of the DNA during its penetration. This is in contrast with natural transformation, where considerable progress has been made in the analysis of the mechanism of DNA uptake. In the best studied naturally transformable species, Streptococcus pneumoniae, double-stranded (ds) DNA is bound to the cell and one strand penetrates while the other is degraded (Lacks, 1962). In this study we have investigated the process of DNA penetration during electrotransformation in this bacterium.

In $S$. pneumoniae a restriction system has been well characterized: $D p n I$ strains do not methylate adenine in GATC sequences and restrict DNA when these sequences are methylated, whereas $D p n I I$ strains methylate adenine in this sequence and do not restrict nonmethylated DNA (Vovis \& Lacks, 1977). A strain deficient in restriction and methylation is also available (Dpn0) (Muckerman et al., 1982). Using this panel of strains we have found that DNA is fully restricted when penetrating by electrotransformation in appropriate strains. This suggests that in contrast to natural transformation, dsDNA penetrates into the cells without an intermediate step where it is converted to a single strand. Single-stranded (ss) DNA was found to electrotransform very weakly; linearized plasmid DNA yielded barely detectable transformants.

\section{METHODS}

Strains and plasmids. Strain R800, a derivative of Avery's strain R36A, contains the DpnI restriction endonuclease. Strain 8R1 is Berheimer's strain MB264 containing the DpnII restriction endonuclease. Our laboratory strain, CP1000, derived from strain RX1 does not contain DpnI or DpnII 
(Dpn0) (Muckerman et al., 1982). The plasmid used in this paper is pLS1 that replicates in Escherichia coli and $S$. pneumoniae (Stassi et al., 1981). It carries a resistance marker for tetracycline. Transformants were selected at a concentration of $1.5 \mu \mathrm{g}$ tetracycline $\mathrm{ml}^{-1}$ after incubation for $2 \mathrm{~h}$ at $37^{\circ} \mathrm{C}$ for phenotypic expression.

Electrotransformation. Cells were grown in CAT complete medium (Morrison et al., 1983) at $37^{\circ} \mathrm{C}$ and harvested in midexponential phase $\left(\mathrm{OD}_{560} 0 \cdot 3-0 \cdot 4\right)$. They were washed twice and concentrated tenfold in electroporation medium (sucrose, $0.5 \mathrm{M}$; potassium phosphate, $7 \mathrm{mM}, \mathrm{pH} 7.5$; magnesium chloride, $1 \mathrm{mM}$ ). A volume of $0.8 \mathrm{ml}$ cell suspension was poured into a Bio-Rad cuvette, pLS1 plasmid DNA was added at a concentration of $1 \mu \mathrm{g} \mathrm{ml}^{-1}$ and the mixture was kept at $0^{\circ} \mathrm{C}$ for $1 \mathrm{~min}$. The Bio-Rad apparatus was set at maximum $\left(6 \cdot 25 \mathrm{kV} \mathrm{cm}^{-1}, 25 \mu \mathrm{F}\right)$. A single pulse of current was given.

\section{RESULTS}

\section{Evidence for DNA restriction during electrotransformation}

To investigate whether DNA is restricted in the process of electrotransformation, we have used three pneumococcal strains: strain R800 produces the $D p n I$ endonuclease that cleaves DNA at GATC sequences methylated at the adenine residue and does not produce the corresponding methylase; strain 8R1 produces the $D p n I I$ endonuclease that cleaves DNA at non-methylated GATC sequences and contains the corresponding methylase; and strain CP1000 is deficient in both restriction-modification systems (Dpn0) (Muckerman et al., 1982). pLS1 DNA was prepared in each of these strains and used to electrotransform the others. Table 1 shows that the $D p n 0$ strain accepts all three kinds of plasmid DNA. When DNA was extracted from 8R1, a $D p n I I$ strain which methylates DNA, there were no transformants of the recipient $D p n \mathrm{I}$ strain that is able to cleave methylated GATC sequences. When plasmid DNA was prepared from the $D p n 0$ or $D p n I$ strains, the frequency of transformation was much higher. Therefore, there appears to be a strong restriction of non-methylated DNA during electrotransformation. Reciprocal experiments were performed with electrotransformation of the DpnII strain. Transformants could only be obtained when DNA was prepared in the same strain.
Table 2. Electrotransformation of denatured DNA

Strain 8R1 (DpnII) was electrotransformed by pLS1 DNA denatured for $5 \mathrm{~min}$ in boiling water then chilled in liquid nitrogen. Conditions of electroporation are as described in the legend to Table 1 . Frequencies shown are the ratio of transformants to surviving bacteria. The percentage survival after treatment is shown in parentheses.

\begin{tabular}{|lc|}
\hline Source of plasmid DNA & $\begin{array}{c}\text { Frequency of } \\
\text { transformation }\end{array}$ \\
\hline 8R1 native (methylated) & $4 \times 10^{-4}(74)$ \\
8R1 denatured (methylated) & $6.9 \times 10^{-5}(44)$ \\
CP1000 native (non-methylated) & $<10^{-8}(81)$ \\
CP1000 denatured (non-methylated) & $4.6 \times 10^{-6}(46)$ \\
\hline
\end{tabular}

There was no transformation when DNA was extracted from both $D p n 0$ and $D p n I$ strains which do not methylate DNA GATC sequences. Thus, DNA is restricted. This also shows that there is no methylase activity detectable in the $D p n 0$ strain as reported in experiments on phage restriction (Muckerman et al., 1982).

Similar experiments were performed using buffer of higher ionic strength to increase the intensity shock. Under these conditions survival was lower but the frequency of transformation was not improved and restriction was still a barrier.

Since such restriction enzymes act only on dsDNA and not on ssDNA (Cerritelli et al., 1989), these experiments suggest that DNA penetrates the cell as a doublestranded molecule. This is different from the situation in natural transformation where DNA becomes singlestranded inside pneumococcal cells. It was of interest to determine if denatured or other forms of DNA could transform cells.

\section{Electrotransformation by denatured DNA}

Preparations of plasmid pLS1 were boiled, chilled in liquid nitrogen and used for electroporation. When the DNA originated from the same strain as the recipient,

\section{Table 1. Restriction of plasmid DNA during electrotransformation}

Plasmid pLS1 was extracted from strains that differ in their restriction-modification states: CP1000 (Dpn0), endonuclease ${ }^{-}$ methylase ${ }^{-} ; \mathrm{R} 800(D p n \mathrm{I})$ endonuclease $\mathrm{I}^{+}$methylase ${ }^{-}$; 8R1 (DpnII) endonuclease $\mathrm{II}^{+}$methylase ${ }^{+}$. Electroporation was performed in a $0.4 \mathrm{~cm}$ cuvette at $2.5 \mathrm{kV}$ with a capacity of $25 \mu \mathrm{F}$ without the pulse controller. DNA was added at a concentration of $1 \mu \mathrm{g} \mathrm{ml}{ }^{-1}$. Frequencies shown are the ratio of transformants to surviving bacteria. The percentage survival after treatment is shown in parentheses.

\begin{tabular}{|lccc|}
\hline Recipient strain & \multicolumn{2}{c|}{ Frequency of transformation with plasmid DNA from: } \\
\cline { 2 - 4 } & CP1000 (non-methylated) & $\mathbf{R} 800$ (non-methylated) & 8R1 (methylated) \\
\hline CP1000 $(D p n 0)$ & $5 \cdot 1 \times 10^{-4}(81)$ & $1 \cdot 8 \times 10^{-3}(38)$ & $1 \cdot 6 \times 10^{-4}(75)$ \\
R800 $(D p n I)$ & $2 \cdot 4 \times 10^{-3}(51)$ & $2 \times 10^{-4}(25)$ & $<10^{-8}(81)$ \\
8R1 (DpnII) & $<10^{-8}(81)$ & $<10^{-8}(29)$ & $4 \times 10^{-4}(74)$ \\
\hline
\end{tabular}


Table 3. Effect of linearization of DNA on electrotransformation

pLS1 DNA was digested by BglI which cuts the circular form. Conditions of electroporation are as described in the legend to Table 1. Frequencies shown are the ratio of transformants to surviving bacteria. The percentage survival after treatment is shown in parentheses.

\begin{tabular}{|ccccc|}
\hline Recipient strain & \multicolumn{4}{c|}{ Frequency of transformation with plasmid DNA from: } \\
\cline { 2 - 5 } & $\begin{array}{c}\text { CP1000 circular } \\
\text { (non-methylated) }\end{array}$ & $\begin{array}{c}\text { 8R1 circular } \\
\text { (methylated) }\end{array}$ & $\begin{array}{c}\text { CP1000 linear } \\
\text { (non-methylated) }\end{array}$ & $\begin{array}{c}\text { 8R1 linear } \\
\text { (methylated) }\end{array}$ \\
\hline R800 (DpnI) & $\begin{array}{c}2 \cdot 4 \times 10^{-3}(51) \\
<10^{-8}(81)\end{array}$ & $\begin{array}{c}<10^{-8}(81) \\
4 \times 10^{-4}(74)\end{array}$ & $\begin{array}{c}3 \times 10^{-8}(22) \\
<10^{-8}(42)\end{array}$ & $\begin{array}{c}<10^{-8}(37) \\
1 \times 10^{-8}(53)\end{array}$ \\
\hline
\end{tabular}

denatured DNA yielded transformants, although at a somewhat lower frequency than native DNA (three- to tenfold less) (Table 2). To determine the origin of these transformants, the denatured DNA was analysed by electrophoresis and the bands were scanned. The ssDNA represented between 30 and $50 \%$ of the total DNA. It resulted mostly from the denaturation of the open circle (oc) form, whereas the CCC form present was very likely due to spontaneous renaturation after the return to room temperature of the boiled DNA. The transformants might result from these double-stranded forms. To define the contribution of ssDNA to electrotransformation, we used samples of the same boiled preparation to electrotransform the restricting strain 8R1 in which dsDNA did not yield any transformants. Transformants were obtained at a much reduced frequency (Table 2). We assume that they originated from the ssDNA which is protected from the restriction enzyme. Taking into account that these preparations contain $45 \%$ ssDNA, the efficiency of this DNA is $2.5 \%$ as compared to dsDNA.

\section{Effect of linearization of DNA on electrotransformation}

pLS1 DNA was linearized by $B g l \mathrm{I}$, which cuts the circular form once, to test its ability to yield transformants. Very few transformants were obtained with the non-restrictive strains, whereas transformants could not be detected with the restricting strains as expected (Table 3).

\section{DISCUSSION}

The results reported here demonstrate that DNA is strongly restricted when it penetrates pneumococcal cells by electrotransformation. The DNA is degraded by the $D p n \mathrm{I}$ and $D p n \mathrm{II}$ restriction endonucleases acting on GATC sequences in the DNA of several pneumococcal strains. Occurrence of a restriction barrier in electrotransformation has been reported for some bacteria such as Corynebacterium glutamicum, Brevibacterium flavum and E. coli (Miller et al., 1988; Bonamy et al., 1990; Vertès et al., 1993; Tauch et al., 1994), whereas in other bacteria such as Lactococcus lactis, Brevibacterium lactofermentum or Yersinia spp. the electrotransformed plasmids apparently can escape the restriction systems present (Langella \& Chopin, 1989; Bonnassie et al., 1990; Conchas \& Carniel, 1990; Cutrin et al., 1994; Vertès et al., 1993). This failure to degrade DNA could be explained by the inactivation of some restriction systems during the electric shock or by a mechanism that protects the entering plasmid DNA against enzymic degradation. It has been reported that uptake of DNA measured by its resistance to added DNases requires a few seconds, whereas the electric pulse only lasts a few milliseconds (Eynard et al., 1992). During this lapse of time some interaction between the DNA and the cell components in the cell envelope might occur. Restriction during electrotransformation could explain the negative or very poor results in attempts to electrotransform bacteria by plasmids produced by other strains or species. Isolation of restriction-negative mutants could improve the general efficiency of electrotransformation using restricted plasmids. In pneumococci it should be possible to easily isolate such mutants by counter selection since the $D p n \mathrm{I}$ or $D p n$ II restriction systems are so efficient. Restriction-negative mutants have been obtained in Brevibacterium lactofermentum and these show improved electrotransformation efficiency (Bonnassie et al., 1990).

In $S$. pneumoniae the restriction of plasmid DNA suggests that DNA is double-stranded when it enters the cells during electrotransformation since this restriction system acts only on dsDNA (Cerritelli et al., 1989). This is quite different from the uptake of DNA in naturally competent cells where a ssDNA step is required (Lacks, 1962). An alternative hypothesis would be that DNA is separated by the electric treatment in single strands which penetrate the cell, reanneal and become susceptible to the restriction enzyme. This is unlikely since the electric field by itself does not modify the plasmid structure (data not shown).

The single-stranded fraction of boiled plasmid preparations is able to yield transformants but at a very reduced frequency. This was also reported for electrotransformation by single-stranded $\alpha 3$ phage DNA (Taketo, 1988). This could result from reduced penetration, hypersensitivity to nucleases of ssDNA inside the cell or inability to resume replication. None of these possibilities can be excluded. Linear DNA yields very 
few transformants. Similar observations were reported for electrotransformation of lactic Streptococci (Powell et al., 1988) and for calcium-dependent transformation of E. coli (Oishi \& Coslay, 1972). This can be accounted for either by a failure to replicate linearized plasmid DNA or extensive degradation by DNases active on linear dsDNA but not on circular DNA. This latter hypothesis is supported by the improved transformation of linear DNA in recBCD-deficient $E$. coli mutants and might also apply to $S$. pneumoniae since this enzyme is active in this bacterium (Vovis, 1973). Further work on electroporation of linear DNA is in progress.

\section{ACKNOWLEDGEMENTS}

We thank Dr H. Krisch and Dr J. Teissié for their kind help in preparing the manuscript.

\section{REFERENCES}

Avery, O. T., MacLeod, C. M. \& McCarty, M. (1944). Studies on the chemical nature of the substance inducing transformation of the pneumococcus types. J Exp Med 79, 137-158.

Bonamy, C., Guyonvarch, A., Reyes, O., David, F. \& Leblon, G. (1990). Interspecies electro-transformation in Corynebacteria. FEMS Microbiol Lett 66, 263-270.

Bonnassie, S., Burini, J. F., Oreglia, J., Trautwetter, A., Patte, J. C. \& Sicard, A. M. (1990). Transfer of plasmid DNA to Brevibacterium lactofermentum by electrotransformation. J Gen Microbiol 136, 2107-2112.

Cerritelli, S., Springhorn, S. S. \& Lacks, S. A. (1989). DpnA, a methylase for single-strand DNA in the DpnII restriction system, and its biological function. Proc Natl Acad Sci USA 86, 9223-9227.

Chassy, B. M., Mercenier, A. \& Flickinger, J. (1988). Transformation of bacteria by electroporation. Trends Biotechnol 6, 303-309.

Conchas, R. F. \& Carniel, E. (1990). A highly efficient electroporation system for transformation of Yersinia. Gene 87, 133-137.

Cutrin, J. M., Conchas, R. F., Barja, J. L. \& Toranzo, A. E. (1994). Electrotransformation of Yersinia ruckeri by plasmid DNA. Microbiologia (Madr) 10, 69-82.

Eynard, N., Sixou, S., Duran, N. \& Teissié, J. (1992). Fast kinetics studies of Escherichia coli electrotransformation. Eur J Biochem 209, 431-436.

Klenchin, V. A., Sukharev, S. I., Serov, S. M., Chemomordik, L. V. \& Chizmkzhev, Y. A. (1991). Electrically induced DNA uptake by cells is a fast process involving DNA electrophoresis. Biophys J 60, 804-811.

Lacks, S. A. (1962). Molecular fate of DNA in genetic transformation of pneumococcus. J Mol Biol 5, 119-131.

Langella, P. \& Chopin, A. (1989). Effect of restriction-modification systems on transfer of foreign DNA into Lactococcus lactis subsp. lactis. FEMS Microbiol Lett 59, 301-306.

Miller, J. F., Dower, W. J. \& Tompinks, L. S. (1988). High-voltage electroporation of bacteria: genetic transformation of Campylobacter jejuni with plasmid DNA. Proc Natl Acad Sci USA 85, 856-860.

Morrison, D. A., Lacks, S. A., Guild, W. R. \& Hageman, J. M. (1983). Isolation and characterization of three new classes of transformation deficient mutants of Streptococcus pneumoniae that are defective in DNA transport and genetic recombination. $J$ Bacteriol 156, 281-290.

Muckerman, C. C., Springhorn, S. S., Greenberg, B. \& Lacks, S. A. (1982). Transformation of restriction endonuclease phenotype in Streptococcus pneumoniae. J Bacteriol 152, 183-190.

Oishi, M. \& Cosloy, S. D. (1972). The genetic and biochemical basis of the transformability of Escherichia coli K12. Biochem Biophys Res Commun 49, 1568-1572.

Powell, I. B., Achen, M. C., Hillier, A. J. \& Davidson, B. E. (1988). A simple and rapid method for genetic transformation of lactic streptococci by electroporation. Appl Environ Microbiol 54, 655-660.

Stassi, D. L., Lopez, P., Espinosa, M. \& Lacks, S. A. (1981). Cloning of chromosomal genes in Streptocococus pneumoniae. Proc Natl Acad Sci USA 78, 7028-7032.

Taketo, A. (1988). DNA transfection of Escherichia coli by electroporation. Biochim Biophys Acta 949, 318-324.

Tauch, A., Kirchner, O., Wehmeier, L., Kalinowski, J. \& Puhler, A. (1994). Corynebacterium glutamicum DNA is subjected to methylation-restriction in Escherichia coli. FEMS Microbiol Lett 123, 343-348.

Vertès, A. A., Inui, M., Kobayashi, M., Kurusu, Y. \& Yukawa, H. (1993). Presence of mrr- and mcr-like restriction systems in coryneform bacteria. Res Microbiol 144, 181-185.

Vovis, G. F. (1973). Adenosine triphosphate-dependent deoxyribonuclease from Diplococcus pneumoniae: fate of transforming deoxyribonucleic acid. J Bacteriol 113, 718-723.

Vovis, G. F. \& Lacks, S. A. (1977). Complementary action of restriction enzymes endo R.DpnI and endo R.DpnII on bacteriophage f1. J Mol Biol 115, 525-538.

Received 24 June 1996; revised 16 September 1996; accepted 23 September 1996. 